\title{
THE CHLOROPHYLL CONTENT, WEIGHT LOSS, AND PRODUCTION OF PAKCOY IN SEVERAL FARMING SYSTEM
}

\author{
Yeyen Prestyaning Wanita ${ }^{1}$ and Riefna Afriani ${ }^{1}$ \\ ${ }^{1}$ Yogyakarta Assessment Institute of Agricultural Technology (AIAT)
}

\begin{abstract}
The research about the chlorophyll content, weight loss, and production of pakcoy in several farming system has been conducted in Yogyakarta AIAT in Juni - December 2016. The experimental design used was a Randomized Block Design with four treatments and six replications. The treatment used were four pakcoy farming system ie. beds, verticulture, polybags, and hydroponics. The results showed that: 1) The beds and hydroponic farming system produce the highest chlorophyll content compared to the other two treatments $(0.64 \mathrm{mg} / 100 \mathrm{~g})$. 2) On 1 - 5 days after harvest, beds farming system had the highest shrinkage $(40-80 \%) .3$ ) The hydroponic farming system produce the lowest weight loss after 5 day harvest (20\%) .4) From the physical appearance, on the sixth day after harvest, pakcoy plants in all ways of farming not suitable for consumption. 5) The verticulture farming system produce the highest total harvest weight compared to the other three farming system ie. $5.91 \mathrm{~kg} / 2 \mathrm{~m}^{2}$. 5) The verticulture farming system produce the highest total harvest weight compared to the other three farming system ie. $5.91 \mathrm{~kg} / 2 \mathrm{~m}^{2}$.
\end{abstract}

Keywords: Pakcoy, farming system, chlorophyll content, weight loss, production

\section{INTRODUCTION}

Vegetables are one of the staple food companions which contain protein, chlorophyll, fiber, vitamins and minerals that are important to fulfilling community nutrition. In 2016, the consumption of vegetables in Indonesia less than $50 \%$ of consumption recommended [1]. The level of public consumption is around 173 grams / capita / day, smaller than the number of nutritional needs of 400 grams / capita / day (RDA). In addition, only $97.3 \%$ of the total population consumes vegetables. In big cities or in agricultural centers, the conversion of agricultural land into settlements is inevitable. Even though food needs for humans especially vegetables are increasing along with the development of the population, the right and efficient farming system model needed for the agricultural business model as one of the solutions that should be considered to overcome food problems [2]. Therefore, the development of horticulture especially vegetables is expected to be able to meet domestic consumption and increase farmers' income. The effort to increase farmers' income done through an appropriate farming system, one of which is the selection of a farming system [3].

There are several farming systems that can be implemented by vegetable farmers including beds, polybag, verticulture, and hydroponic systems. The choice of a farming system depends on several factors ie. the availability of land, the level of knowledge and skills of farmers, market share, and other consideration factors [3]. In sub-optimal land such as narrow land, land management and utilization is carried out so that land potential can be increased. Hydroponic and verticulture farming systems are an alternative for farmers who own land or who only have a narrow yard to be able to carry out business activities that can be used as an adequate source of income. The polybag culture system is carried out when the yard does not have land as a medium for growing plants. Whereas the beds farming system if it has a large yard and the availability of land for farming is sufficient. The different farming systems affect the amount of nutrients in the planting medium which ultimately affects the physical and chemical performance of the plant, as well as the results obtained [4, 5]. Almost all types of vegetables can be cultivated use beds, polybag, verticulture and hydroponics, include pakcoy.

The pakcoy is a type of vegetable favored by all levels of society. This plant can grow in the lowlands and highlands [6]. Indonesia is able to produce pakcoy 8 - 10 tons / ha [3]. While the productivity of pakcoy in Yogyakarta in 2015 amounted to 114.32 quintals / ha [7]. The part of pakcoy plant which has economic value is the leaf part. This plant is a short-lived plant and has nutrients that are beneficial to the body, including chlorophyll. With the different farming systems, it is possible that the types and doses of nutrients given to plants are different, so production, shelf life, weight loss, and nutrient content (chlorophyll) of pakcoy plants will also be different [8]. The different nutrient doses in the farming of pakcoy will affect plant growth [9].

This study aims to determine the effect of beds, polybag, verticulture, and hydroponic farming systems on chlorophyll content, weight loss, and production of pakcoy plants.

\section{METHODOLOGY}

The research was conducted at the Yogyakarta Agricultural Technology Research Institute (AIAT) in January - June 2017. The experimental design used was a randomized block design with 4 (four) treatments and six replications [10]. The treatments used were four pakcoy farming systems namely beds, verticulture, polybags, and hydroponics. In each farming system planted in an $2 \mathrm{~m}^{2}$ area.

The planting material for verticulture systems was a mixture of soil, husk and manure with ratio 1: 1: 1. In

*Coresponding Author : yeyen world@yahoo.com 
beds farming systems, beds were made as high as $30 \mathrm{~cm}$. Distance of rows in beds of $15 \mathrm{~cm}$ and spacing of $10 \mathrm{~cm}$. 3 days before planting manure was given evenly on beds as much as 10 tons / ha. Subsequent fertilization using urea at $130 \mathrm{~kg} / \mathrm{ha}$ was given after 2 weeks of planting. The polybag farming system use mixed media of soil, husk and manure with ratio 1: 1: 1. The hydroponic farming system uses rock wool media measuring $1.5 \mathrm{x}$ $1.5 \mathrm{~cm}^{2}$.

The nutrition given to plants in a hydroponic farming system depends on plant needs. The pakcoy with hydroponic farming system use $\mathrm{AB}$ Mix nutrition. The pakcoy require 1050 - $1400 \mathrm{ppm}$ nutrients with $\mathrm{pH}$ of 7.0 [11]. The fertilization for hydroponics gave at the beginning of growth, which was half of the plant needs (600 ppm). With the increasing age of the plant, the nutrients provided also increase $(1050 \mathrm{ppm})$. The harvesting of pakcoy was done when the plant age 25 days after planting (HST). The farming process from four farming system presented at Table 1.

Table 1. The stages of pakcoy farming use 4 types of farming systems (beds, verticulture, polybag and hydroponics).

\begin{tabular}{|c|c|c|c|c|}
\hline \multirow{2}{*}{$\begin{array}{l}\text { The stages } \\
\text { of } \\
\text { farming }\end{array}$} & \multicolumn{4}{|c|}{ The farming systems } \\
\hline & Beds & $\begin{array}{l}\text { Verticultur } \\
\text { e }\end{array}$ & $\begin{array}{l}\text { Polyba } \\
\text { g }\end{array}$ & $\begin{array}{l}\text { Hidroponi } \\
\text { c }\end{array}$ \\
\hline $\begin{array}{l}\text { Seedling } \\
\text { media }\end{array}$ & $\begin{array}{l}\text { Soil + } \\
\text { manure } \\
+ \text { husk }\end{array}$ & $\begin{array}{l}\text { Soil + } \\
\text { manure + } \\
\text { husk }\end{array}$ & $\begin{array}{l}\text { Soil + } \\
\text { manure } \\
+ \text { husk }\end{array}$ & Rock wool \\
\hline $\begin{array}{l}\text { Planting } \\
\text { media }\end{array}$ & $\begin{array}{l}\text { Soil }+ \\
\text { manure } \\
+ \text { husk }\end{array}$ & $\begin{array}{l}\text { Soil }+ \\
\text { manure }+ \\
\text { husk }\end{array}$ & $\begin{array}{l}\text { Soil }+ \\
\text { manure } \\
+ \text { husk }\end{array}$ & $\begin{array}{l}\text { Hydroponi } \\
\text { c culture }\end{array}$ \\
\hline Sprinkling & $\begin{array}{l}\text { Manual } \\
\text { (mornin } \\
\text { g and } \\
\text { evening } \\
\text { ) }\end{array}$ & $\begin{array}{l}\text { Drip } \\
\text { irrigation }\end{array}$ & $\begin{array}{l}\text { Manual } \\
\text { (mornin } \\
\mathrm{g} \text { and } \\
\text { evening } \\
\text { ) }\end{array}$ & - \\
\hline $\begin{array}{l}\text { Fertilizatio } \\
\mathrm{n}\end{array}$ & $\begin{array}{l}\text { NPK (2 } \\
\text { g / } \\
\text { planting } \\
\text { hole) }\end{array}$ & $\begin{array}{l}\text { NPK }(2 \mathrm{~g} / \\
\text { planting } \\
\text { hole })\end{array}$ & $\begin{array}{l}\text { NPK (2 } \\
\text { g/ } \\
\text { planting } \\
\text { hole) }\end{array}$ & $\begin{array}{l}\text { Provision } \\
\text { of } \\
\text { nutrition } \\
\text { by } \\
\text { controlling } \\
\text { TDS and } \\
\text { PH }\end{array}$ \\
\hline
\end{tabular}

Source: primary data

\section{RESULTS AND DISCUSSIONS}

The different farming systems affect the number of plants per square meter, because the total area of each crop farming system will be different. The number of pakcoy plants in $2 \mathrm{~m}^{2}$ from 4 farming systems is presented in Table 2 .

Tabel 2. The number of pakcoy plants in $2 \mathrm{~m}^{2}$ square from 4 farming systems

\begin{tabular}{|l|l|}
\hline The farming system & $\begin{array}{l}\text { The number of plants in } \mathbf{2} \\
\mathbf{m}^{\mathbf{2}}\end{array}$ \\
\hline Vertikulturr & 288 plants \\
\hline Polybag & 30 plants \\
\hline Beds & 30 plants \\
\hline Hidroponic & 88 plants \\
\hline
\end{tabular}

Source: primary data

The verticulture farming system had the highest number of pakcoy plants in $2 \mathrm{~m}^{2}$ square ie. 288 plants, while the polybag and beds system in the same area had 30 plants. The verticulture system is a farming system that is carried out vertically / multilevel so that it is very suitable to be applied to urban areas and limited land areas. The vertical structure, makes it easier for people to treat and cultivate vegetable crops [12]. In this study, verticulture farming was designed using paralon.

\subsection{The Cholophyll Content}

Chlorophyll is a green coloring agent, which functions to absorb solar energy used for photosynthesis. Photosynthesis is the process of changing energy or food in plants which will be sent to all parts of the plant [13]. Chlorophyll content is the total amount of chlorophyll present in pakcoy leaves which affects plant metabolism through photosynthesis. The pakcoy chlorophyll content in 4 farming systems is presented in Table 3.

Table 3. The content of pakcoy chlorophyll aged 25 HST in 4 different farming systems

\begin{tabular}{|l|l|}
\hline Farming system & Chlorophyll content (\%) \\
\hline Verticulture & 0,40 \\
\hline Polybag & 0,36 \\
\hline Beds & 0,64 \\
\hline Hidroponic & 0,64 \\
\hline Source: primary data
\end{tabular}

The highest chlorophyll content in pakcoy is produced by farming systems using beds and hydroponics. While the lowest chlorophyll content of pakcoy leaves was produced by a polybag farming system. Many factors can cause the chlorophyll content in some pakcoy farming systems different, including genetic, sunlight, water, sugar (carbohydrate), nutrition, and other factors.

The optimum temperature for chlorophyll formation between $26^{\circ} \mathrm{C}-30^{\circ} \mathrm{C}$ [14]. Hydroponic and beds farming systems produce the highest chlorophyll content. This is probably due to the fact that both systems receive adequate sunlight, water and nitrogen. Sunlight is the main factor to form chlorophyll, the sunlight radiation functions to activate the division of chlorophyll cells contained in plants. Plants that get enough sunlight will be greener because chlorophyll is automatically activated, while those with less sunlight will turn paler. In verticulture, pakcoy at the bottom was slightly shaded by plants above, because of the wide canopy of plants. This causes the absorption of sunlight on plants at the bottom was not optimal, which affects chlorophyll content also not optimal.

In hidroponic farming system the nutritional needs (especially nitrogen) can be fulfilled optimally according to the needs of pakcoy plants. In beds farming system, the fulfillment of plant nutrients was done by 
fertilization, if the nutrients (especially nitrogen) that were given not accordance with the plants needs, they can still look to the environment because the planting media was relatively wide. This different with polybag and verticulture farming systems where the available growing media were limited, so the nutrients in it were also limited. Moreover, not all nutrients provided can be optimally absorbed by pakcoy plants.

\subsection{The weight loss}

The weight loss is a process of weight loss due to the process of respiration, transpiration and bacterial activity. espiration that occurs in plants is a biological process where oxygen is absorbed to burn organic materials in plants to produce energy followed by expenditure of residual combustion in the form of carbon dioxide gas and water. Water and gas produced, as well as energy will evaporate so the plants lose their weight [14]. The weight loss of pakcoy plants from the four farming system is presented in Table 4.

Table 4. The weight loss of pakcoy plants (25 age) in 4 different farming systems in a $2 \mathrm{~m}^{2}$ square

\begin{tabular}{cllllll}
\hline Farming & \multicolumn{6}{c}{ Weight loss after x observation day (\%) } \\
\cline { 2 - 7 } system & $\mathbf{1}$ & $\mathbf{2}$ & $\mathbf{3}$ & $\mathbf{4}$ & $\mathbf{5}$ & $\mathbf{6}$ \\
\hline Verticulture & 4,19 & 21,31 & 22,62 & 28,28 & 34,01 & 43,86 \\
Polybag & 15,65 & 23,21 & 27,74 & 33,29 & 36,26 & 49,88 \\
Beds & 27,47 & 39,13 & 46,73 & 52,61 & 65,52 & 68,07 \\
Hidroponic & 10,33 & 6,63 & 12,58 & 10,96 & 5,74 & 30,06 \\
\hline
\end{tabular}

Source: primary data

The highest weight loss of the pakcoy plants was produced by the beds farming system. While pakcoy planted with hydroponic systems provide the lowest weight loss. This is likely to occur because in the hydroponic system all nutrients needed by pakcoy plants to grow and develop are sufficient and easily absorbed, so that after harvesting the energy contained in plants is abundant and can be used to carry out metabolic processes to a certain extent. While the pakcoy farming with beds, verticulture and polybag system not all nutrients needed by pakcoy plants can be fulfilled. Planting media in the form of a mixture of soil, husks and manure contains many nutrients, but not all nutrients contained in the mixed media can be absorbed by pakcoy plants optimally. Thus, the energy content contained in plants with this farming system is not as much as in plants cultivated with hydroponic systems. In addition, hydroponic pakcoy farming systems can prevent the emergence of various types of pests that often damage crops and become wilted, so that energy in plants can be stored optimally [16].

\subsection{The plant production}

The production of pakcoy plants was influenced by the number of plants per farming area. The highest production of pakcoy plants was produced by a verticulture system, which was $5.91 \mathrm{~kg} / 2 \mathrm{~m} 2$. This was due to the fact that per $2 \mathrm{~m} 2$ square, the verticulture farming system can accommodate 288 plants, while the other farming systems are only 30 plants for beds and polybag systems, and 88 plants for hydroponic systems.

Table 5. The pakcoy plants total weight (25 age) from 4 different farming systems in $2 \mathrm{~m}^{2}$

\begin{tabular}{ll}
\hline Farming system & Total plant weight (kg) \\
\hline Verticulture & 5,91 \\
Polybag & 1,50 \\
Beds & 0,70 \\
Hidroponic & 2,54 \\
\hline
\end{tabular}

Source: primary data

\section{CONCLUSION}

The pakcoy farming system can be carried out using four systems, namely beds, polybags, beds, and hydroponics depending on the area of land owned. The pakcoy plants produced by hydroponic farming systems provide the longest shelf life and highest chlorophyll content. Verticulture farming systems produce the highest production / total harvest compared to the other three farming systems (polybags, beds and hydroponics).

\section{REFERENCES}

1. BMKG. Tren konsumsi dan produksi buah dan sayur. Buletin Pemantauan Ketahanan Pangan. In https://docs.wfp.org/api/documents/WFP0000024091/d. (2018). Last Accessed 4 Desember 2018.

2. Roidah I. S. Pemanfaatan lahan dengan mrnggunakan sistem hidroponik. Jurnal Universitas Tulungaagung Bonorowo Vol. 1 (2): 43-49. 2014

3. Agriculture Ministry. Paduan Obor Pangan Lestari (OPAL). (2019)

4. D. Harvani, H. S. Utami, and T. Istivania. Pengaruh penggunaan nutrisi tanaman dengan menggunakan media yang berbeda pada tanaman Pakchoy (Brassica juncea L.) hidroponik. (2014). In http://himatan.ilmutanah.unpad.ac.id/pengaruhpenggunaan-nutrisi-tanaman-denganmenggunakan-media-yang-berbeda-pada-tanamanpakchoi-brassica-juncea-l-hidroponik/. Last Accessed 21 Juli 2019.

5. D. Erawan., W. O. Yani., and A. Bahrun. Pertumbuhan dan hasil tanaman sawi (Brassica juncea L.) pada berbagai dosis pupuk urea. Jurnal Agroteknologi Vol. 3, No. 1, pp.19-25. (2013).

6. Haryanto, Eko, T. Suhartini, E. Rahayu, dan H. Sunarjono. Sawi dan Selada. Peneber Swadaya. Jakarta. (1995). 
7. BPS DIY. Produktivitas tanaman sayur-sayuran menurut jenisnya di Kabupaten/Kota di DI. Yogyakarta (Kwintal/Ha). Dalam https://yogyakarta.bps.go.id/dynamictable/2018/02/ 01/105/produktivitas-tanaman-sayur-sayuranmenurut-jenisnya-dan-kabupaten-kota-di-d-iyogyakarta-kwintal-ha-.html. (2018). Last Accessed 3 Desember 2018.

8. Perwitasari, B., M. Tripatmasari, dan C. Wasonowati. Pengaruh media tanam dan nutrisi terhadap pertumbuhan dan hasil tanaman sawi pakchoi (Brassica juncea L.) dengan sistem hidroponik. Jurnal Agrovigor Vol 5, No. 1, pp. 14 24. (2012).

9. Lingga, P. dan Marsono. Petunjuk Penggunaan Pupuk. Edisi Revisi Penebar Swadaya. Jakarta. (2007).

10. Steel, R.G.D. and J.H. Torrie, 1993. Principples and Procedures of Statistics. A Biomedical Approach, 3rd Ed. Mc Graw Hill, Kagasukha Ltd., Tokyo.

11. Bayu, W. N. 2019. Tabel ppm dan pH nutrisi hidroponik.

Dalam

http://hidroponikpedia.com/tabel-ppm-dan-phnutrisi-hidroponik/. Diunduh tanggal 19 Juli 2019.

12. Lukman, L. Teknologi budidaya tanaman sayuran secara vertikultur. Juknis budidaya sayuran. Balai Penelitian Tanaman Sayuran. (2018). Dalam http://www.litbang.pertanian.go.id/berita/one/918/fi le/verikultur.pdf. Last Accessed 3 Desember 2018.

13. Zakiyah, M., T. F. Manurung, R.S. Wulandari. 2018. Kandungan klorofil daun pada empat jenis pohon di Arboretum Sylva Indonesia PC. Iniversitas Tanjungpura. Jurnal Hutan Lestari. Vol. 6 (1): 48 - 55. (2004).

14. D. Dwidjoseputro. Pengantar Fisiologi Tumbuhan. Gramedia Utama. 1994

15. Yongki, A., Nurlina. 2014. Aplikasi Edible Coating dari Pektin Jeruk Songhi Pontianak (Citrus Nobilis Var Microcarpa) pada Penyimpanan Buah Tomat. JKK, 3(4), 11-20

16. F. Hamli, I. M. Lapanjang, and R. Yusuf. Respon pertumbuhan tanaman sawi (Branssica juncea L.) secara hidroponik terhadap komposisi media tanam dan konsentrasi pupuk organik cair. E-jurnal Agrotekbis, Vol. 3, No. 3, pp. 290 - 296. (2015). 